\title{
On the Evaluation of Subsidy-free Grid-Connected PV Systems in Sunny Countries: an Economic Assessment
}

\author{
R. Peña , A. M. Diez-Pascual , P. García Díaz , I. García
}

\begin{abstract}
In this work, the profitability of investments in subsidy-free grid-connected PV plants is analyzed. So, parameters such as return on investment and payback period have been calculated considering free market conditions (i.e., no incentives to the sold electricity).

The results show that, for an average annual electricity price of $60 \$ / M W h$, IRRs higher than $10 \%$ and payback times shorter than 15 years are possible if plant price is lower than 1.5 $\$ / W p$ and system yield is higher than $1400 \mathrm{kWh} / \mathrm{kWp}$.

If system yield increases to $1600 \mathrm{kWh} / \mathrm{kWp}$, IRRs higher than $10 \%$ are possible for plant price lower than $1.7 \$ / \mathrm{Wp}$.

With regard to payback time, values shorter than 15 years are possible if plant price is lower than $1.5 \$ / \mathrm{Wp}$ and system yield is higher than $1400 \mathrm{kWh} / \mathrm{kWp}$. In order to reduce payback time to 10 years, plant price lower than $1 \$ / \mathrm{Wp}$ and average annual electricity price over $70 \$ / M W h$ would be required.
\end{abstract}

Index Terms - Economic Analysis, PV Market, Funding and Incentives..

\section{Introduction}

Different subsidy-free PV plants have been proposed in last months in some sunny areas, mainly in Southern Europe (Spain, Portugal, Italy) [1]. Even in The United Kingdom, where solar radiation is not so intense, a large plant has been announced under free market conditions.

A previous work of the authors [2] show that current prices for electricity in Spain make it possible to connect large PV plants to the grid under market conditions, with calculated internal rates of return (IRRs) over $10 \%$. This is due to the great reduction in the price of solar panels (and, consequently, in system price). And to the intense solar radiation in the area.

The purpose of this work is to evaluate the profitability of grid-connected PV plants under free market conditions. Special attention will be paid to those areas with higher solar radiation.

The influence of parameters such as system price, wholesale electricity price, annual PV system yield, inflation and other economic variables will be taken into account in all the calculations.

\section{Results}

A software tool has been used [2], which calculates IRR and Payback time for grid-connected PV plants as a function of electricity price, system cost, plant productivity, financial cost and inflation. It can also carry out sensitivity analysis, making it possible to study the influence of the variations in input parameters on the final results. This software, called PVTIR, was developed at the Universidad de Alcalá in a previous project.

\section{A. Influence of system price and average electricity price}

Firstly, the influence of system price and of the average price of electricity have been analyzed. This is shown in figure 1, in which Internal Rate of Return (IRR) is presented as a function of system price and average electricity price in the wholesale market.

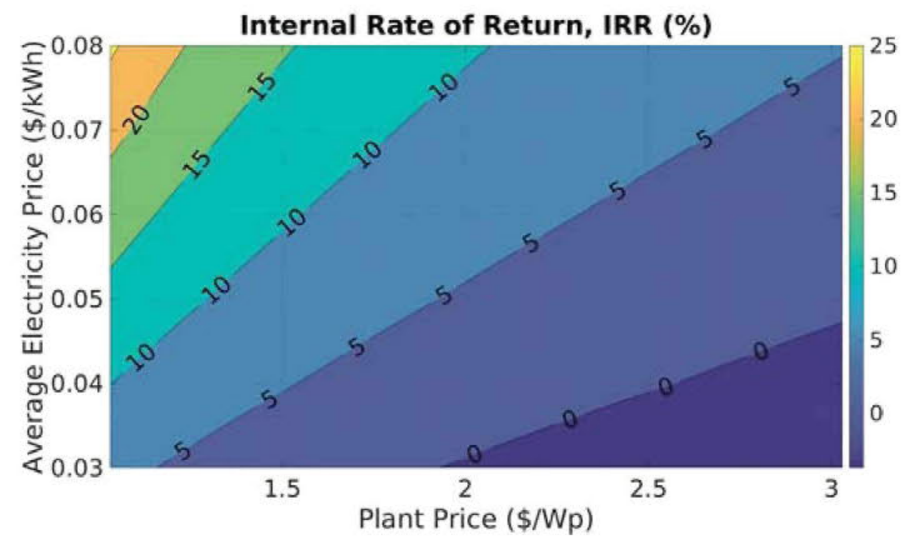

Fig. 1. Internal Rate of Return as a function of system price and average electricity price in the wholesale market. The annual final yield has been fixed to $1400 \mathrm{kWh} / \mathrm{kWp}$. 
In the figure, system price has been varied between 1 and 3 $\$ / \mathrm{Wp}$. These are realistic values in many countries. For instance, in the United States, medium and large size PV installations can be implemented at a price lower than 2.1 \$/W [3].

The average annual electricity price has been varied between 30 and $80 \$ / M W h$. Values in the lower range would correspond to those actually possible in North America, in the middle range are currently typical in the European Union and in the higher range are typical right now in places such as Australia.

The annual final yield has been fixed to $1400 \mathrm{kWh} / \mathrm{kWp}$, possible in many sunny places in PV systems with conventional c-Si PV panels.

The IRRs obtained with these assumptions are higher than $5 \%$ for plant price lower than $1.5 \$ / \mathrm{Wp}$ and average annual electricity price over $40 \$ / \mathrm{MWh}$. If electricity price increases to $60 \$ / M W h$, IRRs higher than $10 \%$ are possible for plant price lower than $1.5 \mathrm{\$} / \mathrm{Wp}$.

Figure 2 shows calculated payback time (that required to recoup the funds expended in the investment) as a function of system price and average electricity price in the wholesale market. The same conditions as in figure 1 have been assumed. The payback time values obtained are long. For plant price lower than $1.5 \$ / \mathrm{Wp}$ and average annual electricity price over $50 \$ / M W h$ (feasible values in Souther Europe), payback times are shorter than 16 years. In order to reduce payback time to 10 years, plant price lower than 1 $\$ / W p$ and average annual electricity price over 70 \$/MWh would be required.

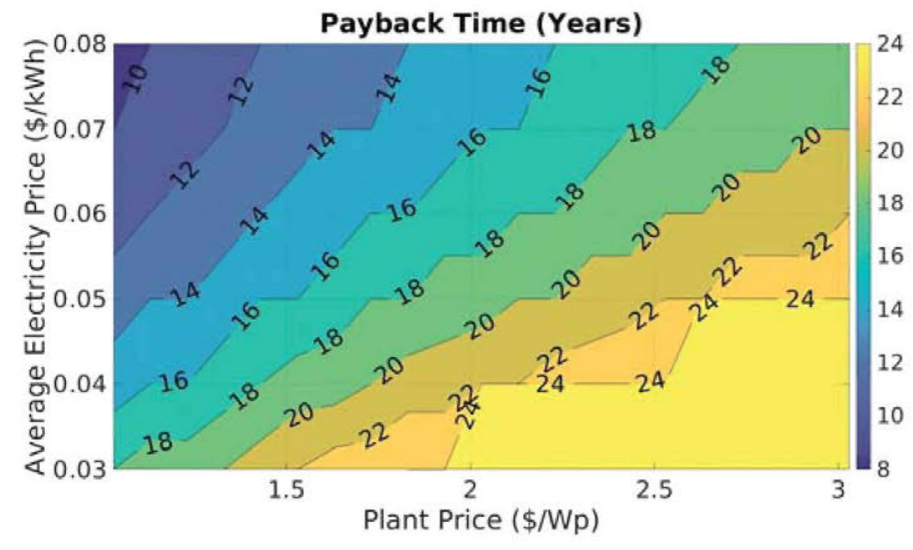

Fig. 2. Payback time as a function of system price and average electricity price. The annual final yield has been fixed to 1400 $\mathrm{kWh} / \mathrm{kWp}$.

\section{B. Influence of system yield}

The influence of system yield is taken into account in this section. So, in figure 3, IRR is presented as a function of average annual yield (in $\mathrm{kWh} / \mathrm{kWp}$ ) and system price. An average annual electricity price of $60 \$ / \mathrm{MWh}$ has been assumed, as in Spain in 2018.

The IRRs obtained are higher than $10 \%$ for plant price lower than $1.5 \$ / \mathrm{Wp}$ and system yield over $1400 \mathrm{kWh} / \mathrm{kWp}$. If system yield increases to $1600 \mathrm{kWh} / \mathrm{kWp}$, IRRs higher than $10 \%$ are possible for plant price lower than $1.7 \mathrm{\$} / \mathrm{Wp}$.

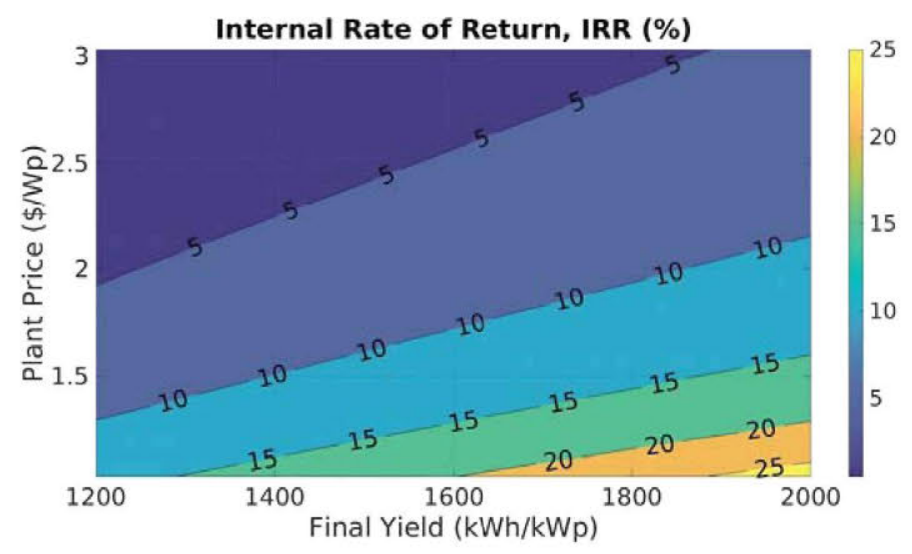

Fig. 3. Internal Rate of Return as a function of average annual yield and system price. An average annual electricity price of $60 \$ / \mathrm{MWh}$ has been assumed.

Figure 4 shows payback time as a function of average annual yield and system price. As in figure 3 , an average annual electricity price of $60 \$ / \mathrm{MWh}$ has been assumed.

The payback time values obtained are shorter than 14 years for plant price lower than $1.5 \$ / W p$ and system yield over $1600 \mathrm{kWh} / \mathrm{kWp}$. If system yield decreases to 1400 $\mathrm{kWh} / \mathrm{kWp}$, payback time values below 15 years are still possible if plant prices are lower than $1.5 \$ / \mathrm{Wp}$.

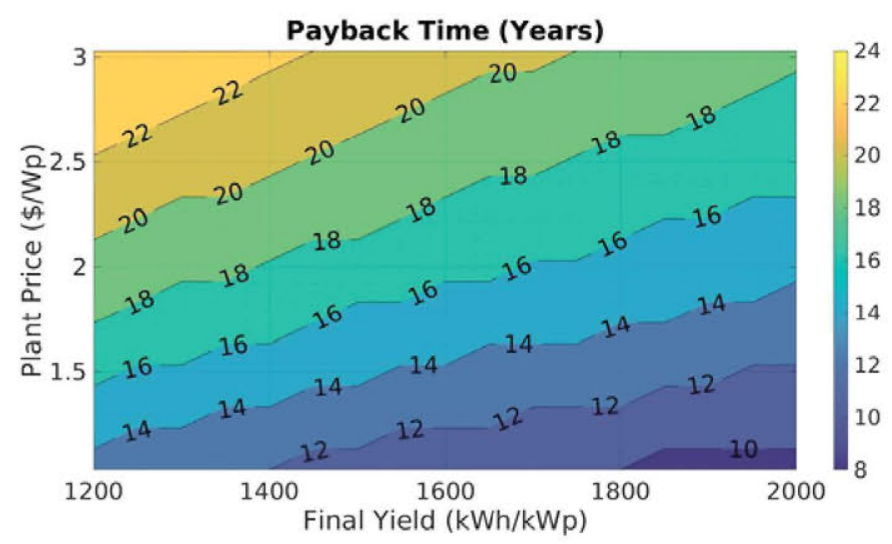

Fig. 4. Payback Time as a function of average annual yield and system price. An average annual electricity price of $60 \$ / \mathrm{MWh}$ has been assumed. 


\section{Discussion and conclusion}

In many sunny locations worldwide, there are actually climatic conditions like those assumed in the calculations in this work. For instance, in Southern Europe (Spain, Portugal, Italy, Greece), Northern África, The middle East, Australia and other Oceania countries, Southern USA, México and Central America, and in tropical and other large areas, the system yields assumed here are perfectly possible.

With regard to system price, the huge reduction in PV panel price over the last years, which has been estimated as $85 \%$ since 2007, make it foreseeable that in a short time the price of $\$ 1$ per watt in large PV systems will be a reality in most countries.

As a conclusion, current prices for electricity in many sunny places make it possible to connect PV plants to the grid under market conditions. In this work, IRR and payback time have been calculated as a function of plant price, wholesale electricity price and annual system yield.

So, for an average annual electricity price of $60 \$ / \mathrm{MWh}$, IRRs calculated here are higher than $10 \%$ if plant price is lower than $1.5 \$ / \mathrm{Wp}$ and system yield is higher than 1400 $\mathrm{kWh} / \mathrm{kW}$.
With regard to payback time, values shorter than 15 years are possible if plant price is lower than $1.5 \mathrm{~S} / \mathrm{Wp}$ and system yield is higher than $1400 \mathrm{kWh} / \mathrm{kWp}$. In order to reduce payback time to 10 years, plant price lower than $1 \mathrm{~S} / \mathrm{Wp}$ and average annual electricity price over $70 \$ / \mathrm{MWh}$ would be required.

Funding: This research was funded by University of Alcalá, via project CCG2018/EXP-01.

\section{References}

[1] https://www.bloomberg.com/news/articles/2018-09-10/solarwithout-subsidy-sprouts-in-europe-no-subsidy-solar. As in January 1, 2019.

[2] R. Peña, A.M. Diez-Pascual, P. Garcia Díaz, J.A. Luceño Sánchez, P. Caño Fernández, "Grid Connected PV Systems in Spain: An Economic Assessment with Sensitivity Analysis", in 35th European Photovoltaic Solar Energy Conference and Exhibition, 2018, p. 2169.

[3] National Renewable Energy Laboratory, "Q2/Q3 2018 Solar Industry Update". www.nrel.gov, as in January 1, 2019. 